Удк 339.181 (075.8)

JEL classification: 022, D81, G32

DOI: https://doi.org/10.35774/visnyk2021.02.103

\title{
Юлія микитюк,
}

доктор фрілософфії, викладач кафедри менеджменту,

публічного управління та персоналу,

Західноукраїнський національний університет,

вул. Львівська, 11, м. Тернопіль, Україна, 46009

e-mail: mykytyuk.yu@gmail.com

ORCID ID: 0000-0002-8519-5809

Євген ПАЛКОВСьКИЙ,

здобувач кафедри менеджменту,

публічного управління та персоналу,

Західноукраїнський національний університет,

вул. Львівська, 11, м. Тернопіль, Україна, 46009

e-mail: ye.palkovskyi@gmail.com

ORCID ID: 0000-0002-8519-5809

\section{ОЦІНКА МАРКЕТИНГОВОЇ ДІЯЛЬНОСТІ ПРОМИСЛОВИХ ПІДПРИЄМСТВ З ВИКОРИСТАННЯМ ЗБАЛАНСОВАНОЇ СИСТЕМИ ПОКАЗНИКІВ}

Микитюк, Ю., Палковський, Є. Оцінка маркетингової діяльності промислових підприємств з використанням збалансованої системи показників. Вісник економіки. 2021. Вип. 2. С. 103-116. DOI: https://doi.org/10.35774/visnyk2021.02.103

Mykytiuk, Yu., Palkovskyi, Y. (2021). Otsinka marketynhovoi diialnosti promyslovykh pidpryiemstv z vykorystanniam zbalansovanoi systemy pokaznykiv [Evaluation of marketing activities of industrial enterprises using a balanced system of indicators]. Visnyk economiky - Herald of Economics, 2, 103-116. DOI: https://doi.org/10.35774/visnyk2021.02.103

\section{Анотація}

Вступ. Велике значення має сумісність збалансованої системи показників маркетингової діяльності (ЗСПМД) $з$ наявними системами показників, які використовують в інших підрозділах підприємства. Таким чином, необхідно забезпечити, щоб цілі ЗСПМД збігалися з цілями, визначеними в інших системах. Крім того, необхідно стежити за тим, щоб показники ЗСПМД не суперечили показникам, які встановлені в інших системах на тому самому рівні, або системи маркетингових показників інших підрозділів підприємства або систему показників у інших функціональних сфрерах.

(C) Юлія Микитюк, Євген Палковський, 2021. 
Ю. Микитюк, Є. Палковський

Оцінка маркетингової діяльності промислових підприємств з використанням ...

Використання збалансованої системи показників, у тому числі для оцінювання маркетингової діяльності, передбачає, що в кожному конкретному випадку може бути використано більшу або меншу кількість перспектив (напрямків оцінювання ефрективності маркетингової діяльності) зі зміною їхнього змісту. Це пов'язано з тим, що складові збалансованої системи показників мають бути розроблені таким чином, щоб задовольнити вимоги найбільш різноманітних підприємств і галузей промисловості. Однак, ці складові є зразком, а не догмою. Немає такої математичної теореми, яка могла б довести, що чотири складові збалансованої системи показників необхідні i достатні. Набагато важливіше в кожному конкретному випадку перевірити, які перспективи є найбільш значущими.

Мета дослідження полягає в аналізі методик оцінювання ефективності маркетингу та обгрунтуванні на їхній основі системного підходу, який враховує основні аспекти маркетингової діяльності та дає змогу здійснити їі комплексне оцінювання.

Методи дослідження. У статті використано загальнонаукові та спеціальні методи пізнання, а саме: індукції та дедукції (для дослідження теоретикометодичних основ щодо аналізу маркетингової діяльності промислових підприємств); системного аналізу (для визначення сукупності методичних засобів $і$ практичних прийомів, що використовуються для прийняття управлінських рішень у процесі діяльності промислових підприємств); діалектичний метод (поглиблює пізнання процесів у їхньому тісному взаємозв'язку та постійному розвитку); графрічний метод (подання досліджуваних явищ і процесів у вигляді ілюстрацій).

Результати. У процесі дослідження доведено, що система показників ефрективності маркетингової діяльності промислового підприємства має містити фактори, які виокремлюються як ключові для маркетингової діяльності підприємства. Основні індикатори фрункціонування обираються за принципом гармонічності і врівноваженості, тобто збалансованості. У цьому випадку зростає роль і значення концепції збалансованої системи показників.

Дослідження концепції збалансованої системи показників, у тому числі для оцінювання маркетингової діяльності, передбачає, що в кожному конкретному випадку може бути використана більша або менша кількість перспектив зі зміною їхнього змісту. Велике значення має сумісність збалансованої системи показників маркетингової діяльності з уже наявними системами показників, які використовуються в других підрозділах підприємства.

Перспективи. В майбутньому дослідженні планується розробити комплекс системи показників результатів i фракторів маркетингової діяльності. Без урахування цих фракторів неможливо зрозуміти, які досягнені кінцеві результати. Також за допомогою цієї системи показників можливо оцінити на ранніх етапах, наскільки успішно здійснюється маркетингова стратегія підприємства.

Ключові слова: маркетингова діяльність, ефрективність маркетингу, маркетингова служба, управління маркетингом, збалансована система показників.

Формули: 0, рис.: 1, табл.: 2, бібл.: 12. 


\author{
Yuliia MYKYTYUK, \\ Doctor of philosophy, \\ Professor of the Department of Management, \\ Public Administration and Personnel, \\ West Ukranian National University, \\ Street Lvivska, 11, Ternopil, Ukraine, 46009 \\ e-mail: pp.mykytiuk@gmail.com \\ ORCID ID: 0000-0002-3038-6886. \\ Yevgen PALKOVSKYI, \\ Applicant of the Department of Management, \\ Public Administration and Personnel, \\ West Ukranian National University, \\ Street Lvivska, 11, Ternopil, Ukraine, 46009 \\ e-mail: ye.palkovskyi@gmail.com \\ ORCID ID: 0000-0002-3038-6886.
}

\title{
EVALUATION OF MARKETING ACTIVITIES OF INDUSTRIAL ENTERPRISES USING A BALANCED SYSTEM OF INDICATORS
}

\section{Abstract}

Introduction. Of great importance is the compatibility of a balanced system of indicators of marketing activities (BSIMA) with existing systems of indicators used in other departments of the enterprise. Thus, it is necessary to ensure that the objectives of the BSIMA coincide with the objectives defined in other systems. In addition, it is necessary to ensure that the indicators of BSIMA do not contradict the indicators that are set in other systems at the same level or the system of marketing indicators of other divisions of the enterprise or the system of indicators of other functional areas.

The use of a balanced system of indicators, including for the assessment of marketing activities, implies that in each case can be used more or less prospects (areas for assessing the effectiveness of marketing activities) with a change in their content. This is due to the fact that the components of a balanced scorecard must be designed to meet the requirements of a wide variety of enterprises and industries. However, these components are a model, not a dogma. There is no mathematical theorem that can prove that the four components of a balanced scorecard are necessary and sufficient. It is much more important in each case to check which prospects are the most significant.

The purpose of the study is to analyze the methods of evaluating the effectiveness of marketing and justify on their basis a systematic approach that takes into account the main aspects of marketing activities and allows for a comprehensive assessment.

Research methods. The article uses general and special methods of cognition, namely: induction and deduction (in the study of theoretical and methodological foundations for the analysis of marketing activities of industrial enterprises); system analysis (to determine the set of methodological tools and practical techniques used to make management decisions 
in the process of industrial enterprises); dialectical method (deepens the knowledge of processes in their close relationship and constant development); graphic method (representation of the studied phenomena and processes in the form of illustrations).

Results. In the course of the research it is proved that the system of indicators of efficiency of marketing activity of the industrial enterprise should include the factors which are allocated as key for marketing activity of the enterprise. In this case, the key performance indicators are selected on the principle of harmony and balance, ie balance. In this case, the role and importance of the concept of a balanced scorecard increases.

The study of the concept of a balanced scorecard, including for the evaluation of marketing activities, suggests that in each case can be used more or less prospects with a change in their content. Of great importance is the compatibility of a balanced system of indicators of marketing activities with existing systems of indicators used in other divisions of the enterprise.

Discussion. In the future research it is planned to develop a complex system of indicators of results and factors of marketing activity. Without taking these factors into account, it is not possible to understand what the end results have been. Also with the help of this system of indicators it is possible to assess at an early stage how successfully the marketing strategy of the enterprise.

Keywords: marketing activities, marketing efficiency, marketing service, marketing management, balanced scorecard.

Formulas: 0, fig.: 1, tabl.: 2, bibl.: 12.

Постановка проблеми. Сучасний ринок висуває вимоги до керівників маркетингових служб, підрозділів продажу і збуту доведення свого реального вкладу в загальну корпоративну ефективність і капіталізацію підприємства, відображення результатів своєї діяльності в фрінансових показниках дохідності. Однак через недостатній рівень маркетингових знань багато топ-менеджерів і фінансових директорів не здатні правильно розраховувати значущість маркетингових зусиль для підвищення конкурентоспроможності і зростання ринкової вартості підприємства. Водночас вони реально зацікавлені в наявності практичних інструментів, що дало би змогу оцінити ефективність маркетингових рішень і здійснити обґрунтований вибір стратегічних альтернатив.

Аналіз останніх досліджень і публікацій. Вагомий науковий внесок у розвиток методології оцінювання ефективності маркетингової діяльності зробили такі вітчизняні та зарубіжні науковці, як Г. Армстронг, Л. Балабанова, П. Дойль, Р. Капалан, М. Конишева, Ф. Котлер, П. Микитюк, Н. Мойсеєва, Д. Нортон, Е. Патрушева, В. Шаповалов, Д. Шульц та інші. Проте, незважаючи на значну кількість фундаментальних досліджень, проблема обґрунтування системного підходу до оцінювання ефективності маркетингу все ще недостатньо вивчена.

Метою статті $\epsilon$ аналіз методик оцінювання ефективності маркетингу та обґрунтування на їхній основі системного підходу, який враховує основні аспекти маркетингової діяльності та дає змогу здійснити їі комплексне оцінювання. 
Виклад основного матеріалу. Аналіз сучасних методів оцінювання маркетингової діяльності промислового підприємства показав, що, на думку більшості дослідників, в ідеалі показники оцінювання ефективності мають відповідати певним вимогам:

- мінімальність. Необхідно вибрати відносно невелику кількість показників оцінювання ефективності. В іншому разі будуть вичерпані природні ліміти освоєння інформації, і вона буде втрачена;

- корисність для прогнозування. Нефрінансові показники мають передбачати майбутні фрінансові результати, інакше кажучи, нефінансові показники мають бути визначальними показниками ефективності, а фрінансові - лаговими показниками, тобто вони повинні підсумувати результати в міру їх надходження. Нефінансові показники, які були визначальними, можуть бути відкинуті, якщо тільки вони не є для підприємства обов'язковими контрольними показниками з точки зору регулювання, етики та контролю безпеки;

- системний характер. У такому разі показники ефективності маркетингової діяльності підприємства мають три основні переваги перед вузькоспеціалізованими показниками. Ïх можна послідовно простежити від нижчих до вищих рівнів корпорації. Тим самим люди зможуть побачити взаємозв'язок між власними результатами та результатами підприємства. Їх можна проаналізувати у напрямку зверху вниз і дати керівникам вищої ланки можливість простежити ефективність на нижчих ланках. Можна порівняти їх на горизонтальному рівні між різними підрозділами підприємства, сприяючи інноваціям і заохоченню ефективності;

- стабільність. Система управління має бути стабільною. Показники мають змінюватися поступово, щоби персоналу підприємства було відомо про його довготермінову мету і щоб їхня поведінка була передбачувана;

- придатність до компенсації. Ідеальні показники мають бути основою компенсації, яку отримує персонал за свою діяльність (відповідно до фінансових результатів або на основі впливу на фрінансові результати показників нефінансового характеру).

Ці вимоги не є вичерпними. У такому контексті, на нашу думку, важливо мати на увазі таке.

По-перше, інформація, що міститься в системі показників ефективності маркетингової діяльності промислового підприємства, має бути такою, щоб ії можна було швидко і просто застосовувати. Тому особлива увага приділяється такій характеристиці системи, як прозорість.

По-друге, система показників ефективності маркетингової діяльності промислового підприємства повинна підтримувати стратегічні рішення на оперативному рівні й інформувати про відповідні актуальні способи досягнення мети. Вона має відокремлювати дійсно необхідну інформацію від додаткової.

По-третє, система показників ефективності маркетингової діяльності промислового підприємства має бути індивідуальною. Якщо раніше розроблялися системи показників, які можна було б застосовувати протягом максимально тривалого часу, то сьогодні найбільшу актуальність набуває можливість адаптувати систему до індивідуальних умов. Саме в сфері маркетингу це відіграє важливу роль, оскільки мова йде про диференціацію щододо конкурентів і споживачів. 
По-четверте, - і це найголовніше - система показників ефрективності маркетингової діяльності промислового підприємства має охоплювати фактори, що виокремлюються як основні для маркетингової діяльності підприємства. Ключовий індикатор фрункціонування $€$ фактор, критичний для забезпечення майбутнього успіху підприємства [1]. У такому разі головні індикатори функціонування (ключові фрактори успіху) відбираються за принципом гармонійності, врівноваженості, тобто збалансованості.

Найбільш відомим набором основних індикаторів функціонування є збалансована система показників, запропонована Р. Капланом і Д. Нортоном [2, 3]. Збалансована система показників (далі ЗСП) - це ефективний і універсальний інструмент управління для послідовного напрямку дій (діяльності, заходів) групи осіб (організацій, підприємств, інститутів, областей, підрозділів, проектних груп і т.д.) на досягнення спільної мети.

ЗСП має два основні напрями. По-перше, вона діє вертикально, тобто пов'язує керівництво підприємства й інші ієрархічні рівні. По-друге, вона діє горизонтально, тобто переводить фрінансові завдання на «мову» конкретної сфери діяльності.

ЗСП враховує показники, що пов'язані з чотирма координатами бізнесу:

- ринок / клієнти (споживачі) - як споживачі сприймають підприємство;

- внутрішні бізнес-процеси (внутрішня координата) - у чому підприємство перевершує конкурентів;

- інновації та навчання - чи може підприємство вдосконалюватися і створювати цінності;

- фінансова координата - як акціонери й конкуренти бачать підприємство.

Умовою успішної реалізації ЗСП для оцінювання маркетингової діяльності підприємства в процесі взаємодії зі споживачами є динамічний моніторинг ключових індикаторів функціонування. Взаємодія зі споживачами за своєю суттю явище реактивного типу: дія - реакція - коригування - дія. Жорсткий план, який не дозволяє врахувати зворотного зв'язку зі споживачем або змін у зовнішніх умовах, у такому разі не працює. Вирішальним фрактором є відповідальність за успіх. Саме зазначені складові дають змогу забезпечувати ефективність проведеного моніторингу.

Для об'єктивності оцінювання ключові індикатори функціонування мають відповідати таким основним вимогам [4].

По-перше, чітке визначення критеріїв, що дає змогу кожному співробітникові розуміти їх однаково.

По-друге, опираючись на точні дані від співробітників, які не завжди можуть усвідомлювати важливість інформації, що надходить, передавати величезний обсяг інформації про споживачів.

По-третє, орієнтація на дані, які легко отримати. Там, де це можливо, ключові індикатори функціонування мають ґрунтуватися на даних, які отримують у ході звичайного процесу управління взаємовідносинами.

По-четверте, прийнятний рівень акуратності, за якого не виникають можливості для шахрайства, що особливо важливо, якщо ключові індикатори функціонування діють як цільові показники або є частиною схеми стимулювання взаємодії. 
По-п'яте, системність, яка перевіряється негайно для гарантованого обліку даних, необхідних для індикаторів, у місці їх отримання.

По-шосте, установка базових характеристик за фрактичними показниками із залученням більш низьких рівнів первинної інформації. У цьому випадку спочатку визначається основна залежність або залежність вищого рівня, наприклад надходження інвестицій. Потім отриманий показник аналізується за допомогою інших залежностей, які встановлюються послідовно, зверху вниз. Сукупність цих залежностей дає змогу визначити причину проблеми, що цікавить.

Перераховані вимоги забезпечують ЗСП такі переваги. По-перше, ЗСП дає змогу уникнути надлишку інформації, оскільки акцент робиться тільки на ті параметри, які дійсно вважаються основними. Ідея полягає в тому, щоб звести окремі показники разом в рамках єдиного звіту про менеджмент. По-друге, ЗСП, що відповідає вимогам, спонукає менеджерів враховувати загальні операційні показники. По-третє, ЗСП вимагає від менеджерів перехід від загальних до конкретних параметрів.

Немає жодної проблеми в тому, щоб розробити свою власну стратегію. В табл. 1 наведено інтерпретацію ЗСП в сучасному її тлумаченні.

Таблиця 1

\section{Інтерпретація збалансованої системи показників}

\begin{tabular}{|c|c|}
\hline Класична (неправильна) інтерпретація ЗСП & Правильна інтерпретація ЗСП \\
\hline ЗСП - це система показників & $\begin{array}{c}\text { ЗСП - це система управління компанією за } \\
\text { допомогою показників }\end{array}$ \\
\hline $\begin{array}{c}\text { Розробка ЗСП відбувається за принципом } \\
\text { «зверху-вниз» - від керівництва до } \\
\text { нижчестоящим співробітникам } \\
\end{array}$ & $\begin{array}{c}\text { ЗСП - це командо-орієнтована система, яка } \\
\text { задіює всіх співробітників компанії }\end{array}$ \\
\hline ЗСП - це система контролю & $\begin{array}{c}\text { ЗСП орієнтована на майбутнє, тобто } € \\
\text { частиною системи планування. Вона } \\
\text { допомагає перевести процес планування на } \\
\text { рівень оперативного управління }\end{array}$ \\
\hline $\begin{array}{c}\text { ЗСП має чотири стандартні перспективи: } \\
\text { «Відносини з клієнтами», «Фінанси», «Внутрішні } \\
\text { бізнес-процеси», «Навчання і зростання» }\end{array}$ & $\begin{array}{c}\text { ЗСП має більше перспектив, що включають } \\
\text { різну кількість різноманітних показників, для } \\
\text { визначення яких вирішальним фактором є } \\
\text { специфріка компанії }\end{array}$ \\
\hline ЗСП служить для управління всією компанією & $\begin{array}{c}\text { ЗСП може застосовуватися на всіх рівнях } \\
\text { компанії (бізнес-одиниця, відділ, підрозділ). } \\
\text { Для компанії розробляється якась } \\
\text { «піраміда» показників }\end{array}$ \\
\hline
\end{tabular}

Джерело: розроблено авторами.

Табл. 1 дає змогу сформулювати такі основні принципи використання ЗСП для оцінювання ефективності маркетингової діяльності промислового підприємства:

- ЗСП - це інструмент управління, що пов язує стратегічний та оперативний рівні;

- ЗСП дає змогу стежити за тим, щоб різнопланові завдання (насамперед це стосується відносин з клієнтами і фінансами) виконувалися послідовно;

- ЗСП є гнучкою системою і легко адаптується для застосування підприємствами в різноманітних ситуаціях; 
- успішність застосування ЗСП визначається не дотриманням формальностей, а розумінням цілей підприємства усіма співробітниками.

Дотримання вказаних принципів дасть змогу уникнути потенційних конфрліктних ситуацій як горизонтальнх (конфрлікти системи показників одного рівня), так і вертикальних (конфрлікти системи показників різного рівня) і гармонізувати ЗСПМД з ЗСП підприємства.

Гармонізувати ЗСПМД з ЗСП підприємства можна двома способами. По-перше, існує спосіб «зверху вниз», за якого перспективи загально-корпоративної ЗСП переносяться на рівень маркетингу. Цей шлях $€$ деякою мірою консервативним, оскільки використовуючи його, ми можемо майже не змінювати первісну концепцію і точно її дотримуватися. Однак методична точність цього способу залишає відкритим питання про те, наскільки реально врахувати всі особливості маркетингу. По-друге, «природний» спосіб, згідно з яким насамперед необхідно визначити, коли маркетинг знаходиться в своєму «стані гармонії». Необхідні перспективи визначаються на підставі критичних чинників успіху, виявлених під час аналізу зовнішнього середовища і власного досвіду підприємства [5].

Викладені підходи умовні, оскільки кожне підприємство знаходить власний спосіб вирішення завдання. Однак у всіх випадках потрібно дотримуватися основного принципу побудови ЗСПМД - ці перспективи повинні знаходитися у вільних відносинах і охоплювати більшу частину сфер маркетингової діяльності, важливих для успішного розвитку підприємства. Такі відносини означають, що для відбору показників ЗСПМД особливу увагу потрібно приділити причинно-наслідковим зв'язкам між ними. Система дієва лише в тому разі, якщо показники перспектив «Внутрішні бізнес-процеси» і «Навчання та зростання» впливають на перспективи «Фінансів» та «Відносин 3 клієнтами». В іншому випадку, зміни в процесах регулювати буде вкрай складно, а намічених результатів досягти буде практично неможливо.

Інакше кажучи, ЗСПМД - це набір гіпотез про причини і наслідки. У системі оцінювання має чітко виявлятися співвідношення (гіпотези) між цілями і критеріями їх досягнення в різних напрямках, щоб вони були реальними і ними можна було керувати. Ланцюг причинно-наслідкових зв'язків як основний принцип побудови ЗСПМД пронизує всі її складові. Правильно розроблена ЗСПМД має становити цілісний виклад маркетингової стратегії підприємства і чітко визначати послідовність гіпотетичних причинно-наслідкових зв'язків між критеріями результатів і рушійними фракторами їх досягнення. Кожен показник, що входить у ЗСПМД, має бути ланкою в ланцюзі причинно-наслідкових зв'язків, яка доводить до відома всіх працівників підприємства сенс його маркетингової діяльності. 3 викладеного можна запропонувати наступну загальнометодичну схему побудови ЗСПМД з використанням «природного» способу гармонізації ЗСПМД з ЗСП підприємства.

3 цією метою спочатку необхідно виявити місце ЗСПМД в системі маркетингового планування у підприємстві (рис. 1).

Відповідно до рис. 1, активні маркетингові дії повинні здійснюватися постійно і безперервно. Це означає, що перед розробкою ЗСПМД необхідно розробити маркетингову стратегію, ґрунтуючись на цілях і завданнях підприємства загалом і маркетингу зокрема. Головна вимога до системи показників полягає в тому, що вона 
завжди має відповідати стратегії. Результати маркетингового аудиту інтегруються в процес розробки і використання системи показників, щоб удосконалити цілі відповідно до ситуації, а можливо, щоб інтегрувати нові цілі й нові параметри вимірювання ефективності в діяльність організації.

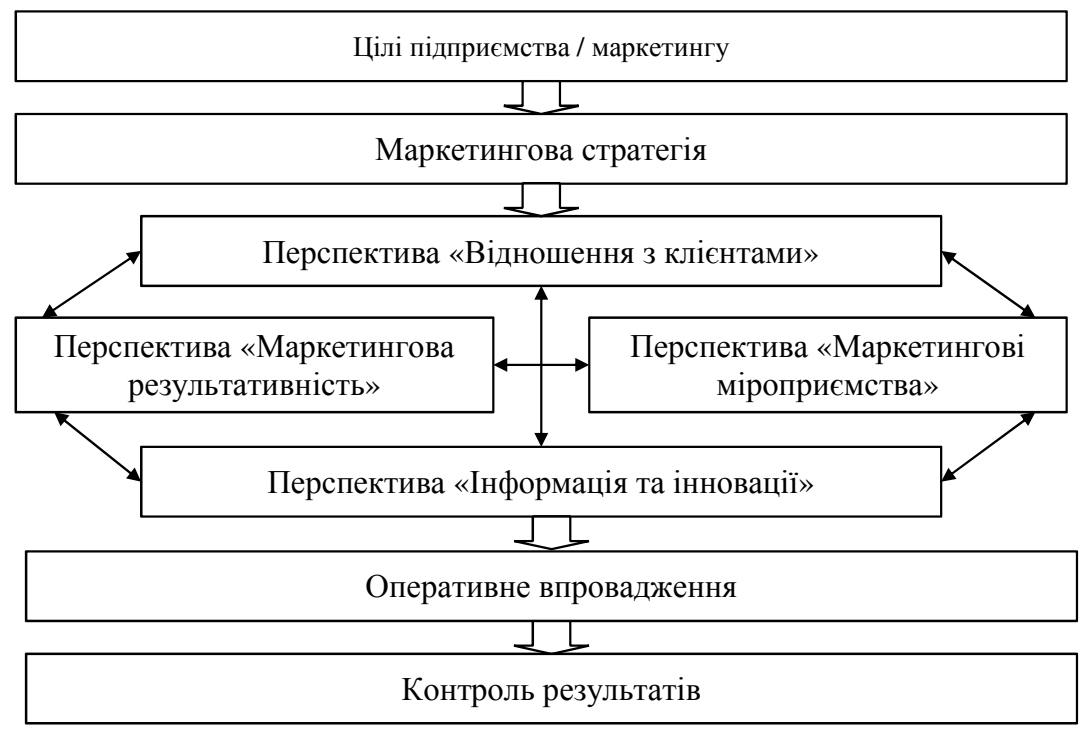

Рис. 1. Місце збалансованої системи показників у маркетинговому плануванні Джерело: розроблено авторами.

3 урахуванням цієї залежності між системою показників і процесом планування можна розробити концепцію впровадження і застосування ЗСПМД. Систему показників щодо маркетингу потрібно розробляти в компанії, де діє вища або загальнокорпоративна система показників. Якщо ця умова не дотримана, необхідність у проведенні процесу «природної» гармонізації $\epsilon$ недоцільною. Така концепція складається з восьми окремих кроків, які в певних випадках можна звести разом, однак важливо кожен окремий крок брати до уваги (рис. 1).

Для розробки ЗСПМД виникає питання про кількість показників, що включаються в систему. Якщо вважати, що кожна з перспектив ЗСПМД матиме від чотирьох до семи різних параметрів, то в ЗСПМД буде включено в середньому 25 показників. Працівники підприємства з недовірою ставляться до твердження, що для ефективного оцінювання операційної діяльності достатньо не більше двох десятків показників. Певною мірою це правильно, але вони пропонують показники діагностики, за якими можна зробити висновок, чи знаходиться бізнес під контролем, і які сигналізують про процеси, що потребують негайного вжиття заходів [6].

ЗСПД охоплює ключові показники реалізації стратегії підприємства. Тому, якщо ЗСПМД розглядати як сукупність більш двох десятків показників, то працювати з ними дуже складно для будь-якого підприємства.

ЗСПМД не замінює систему оцінювання повсякденних параметрів. Показники системи вибираються так, щоб увагу менеджерів і працівників підприємства було 
сконцентровано на тих фракторах маркетингової діяльності, які можуть привести до досягнень ефективних результатів у конкуренції на ринку.

Для розробки і впровадження ЗСПМД постає питання, чи доцільно включати в неї фрінансові показники. Деякі фахівці вважають, що потрібно повністю вилучити фінансові показники як критерій ефективності маркетингової діяльності підприємства, тому що фінансові показники не можуть повною мірою сприяти успіху. Вони лише спонукають менеджерів сконцентрувати зусилля на підвищенні рівня обслуговування споживачів як тимчасовому циклі, а також кваліфікації та мотивації персоналу [7].

На нашу думку, регулярні фінансові звіти та фінансові показники мають відігравати важливу роль, нагадуючи керівництву підприємства, що поліпшення якості термінів виконання замовлень, продуктивність і виробництво нових продуктів та розвиток інших видів маркетингової діяльності $є$ засобом досягнення поставленої мети, але не самою метою. Такі удосконалення приносять підприємству вигоду тільки тоді, коли переносяться в площину збільшення обсягів продажів, скорочення операційних витрат або більш ефективного використання активів. Не всі довгострокові стратегії прибуткові [8].

Система оцінювання та управління повинна чітко вказувати, як вдосконалення маркетингової діяльності пов'язано з поліпшенням фінансової діяльності за рахунок збільшення обсягу продажів, операційного прибутку, прискорення оборотності капіталу, скорочення операційних витрат. У системі збалансованих показників має зберігатися акцент на фінансових результатах. Через причинно-наслідкові зв'язки всі ії показники мають бути прив'язані до фінансових цілей [9].

Як тільки ЗСПМД розроблена, вона стає основою створення збалансованої системи показників для підрозділів і окремих працівників підприємства. Мета й стратегія кожного з них визначається в рамках системи показників ефективності господарської одиниці. Такий підхід пояснюється тим, що ЗСПМД за своєю суттю націлений на гармонізацію інтересів усіх співробітників підприємства відповідно до стратегічної мети його розвитку. Система $є$ комплексною програмою планування ефективної роботи та розвитку кожного співробітника. Вона може водночас служити декільком цілям. Такий підхід дає змогу забезпечити розвиток підприємства і підвищення результативності його діяльності [10].

Щоби правильно виміряти досягнення кожного підрозділу і кожного працівника підприємства, кожен працівник підприємства має визначити єдині, справедливі, зрозумілі і «прозорі» ключові індикатори досягнення результатів (КІДР). Ці індикатори потрібно довести до співробітників на етапі узгодження цілей роботи так само, як умови винагороди, преміювання в разі досягнення цілей, а також внаслідок невиконання цілей [11].

У табл. 2 представлені найбільш важливі фактори, що визначають успіх діяльності працівника підприємства. Джерелом цих факторів послужили його місія, бачення і ключові ролі. Загалом КІДР визначаються відповіддю на таке запитання: які з моїх особистих прагнень мають вирішальне значення для мого особистого благополуччя й успіху?

КІДР - це система індикаторів успішності підприємства, оскільки зниження результатів сигналізує про проблеми, які впливають як на поточні результати 
підприємства, так і потенційно можуть впливати на розвиток бізнесу. Тому КІДР використовуються не тільки для вимірювання результатів, подання звітності, диференціації досягнень, а й для аналізу можливостей поліпшення результатів, вдосконалення і розвитку бізнесу [12].

Таблиця 2

Ключові індикатори досягнення результатів

\begin{tabular}{|c|c|}
\hline Фінансова сфрера & Відносини з оточуючими \\
\hline Фінансова стійкість & $\begin{array}{c}\text { Бути високо оціненим членами сім'ї, друзями, } \\
\text { колегами і роботодавцем } \\
\text { Досягати високої якості роботи }\end{array}$ \\
\hline Внутрішні процеси & Знання і навчання \\
\hline $\begin{array}{c}\text { Підтримувати гармонійні відносини з } \\
\text { колегами, допомагати один одному, } \\
\text { надихати інших і ділитися з ними своїми } \\
\text { знаннями } \\
\text { Намагатися досягти фрізичного здоров'я і } \\
\text { психологічної стійкості } \\
\end{array}$ & $\begin{array}{c}\text { Проявляти ініціативу, вчитися на своїх помилках, } \\
\text { безперервно самовдосконалюватися і } \\
\text { особистісно зростати } \\
\text { Вчитися чомусь новому щодня і ніколи не } \\
\text { переставати вчитися }\end{array}$ \\
\hline
\end{tabular}

Джерело: розроблено авторами.

Менеджери відділів мають розробляти при цьому власні КІДР, що повністю відповідають цілям і маркетинговій стратегії всього підприємства й адекватні ЗСПМД.

Висновки та перспективи подальших досліджень. Система збалансованих показників ефрективності маркетингової діяльності підприємства проєктується на всі локальні центри відповідальності в середині неї, що дає змогу працівникам підприємства працювати відповідно до загальної стратегії.

Загалом успішність впровадження ЗСПМД визначається такими факторами:

- гарантований обсяг топ-менеджменту (підприємства, а також керівників підрозділів маркетингу);

- залучення топ-менеджменту до реалізації найважливіших етапів процесу розробки (створення координаційної групи);

-інформування та навчання осіб, відповідальних за прийняття рішень, а такожінших учасників процесу (наприклад, проведення семінарів з обов'язковим відвідуванням);

- вибір відповідних керівників проєкту і завчасна їх підготовка;

- тренінги для модераторів, які будуть виконувати роль посередників і впроваджувати рішення в окремих департаментах (модераторами можуть бути фахівці і керівники задіяних підрозділів);

- дотримання встановлених оглядових процесів, позначених у концепції проєкту;

- передача досвіду і знань, отриманих у процесі розробки подальших систем показників у компанії;

- відповідність ЗСПМД системам показників інших функціональних напрямків, а також загальнокорпоративної ЗСП.

У майбутньому дослідженні планується розробити комплекс системи показників результатів і фракторів маркетингової діяльності. Без врахування цих фракторів 
неможливо зрозуміти, які кінцеві результати досягнуто. Також за допомогою цієї системи показників можливо оцінити на ранніх етапах, наскільки успішно здійснюється маркетингова стратегія підприємства.

\section{תimepamypa}

1. Антонюк А. А. Вибір підходів до формування показників оцінки ефективності маркетингової діяльності на підприємстві. Держава та регіони. Сер.: Економіка та підприємництво. 2007. № 2. С.11-14.

2. Каплан Роберт С., Нортон Дейвид П. Сбалансированная система показателей. От стратегии к действию / пер. в англ. Москва : ЗАО «Олимп-Бизнес», 2004. $416 \mathrm{c.}$

3. Каплан Р. С., Нортон Д. П. Организация, ориентированная на стратегию. Как в новой бизнес-среде преуспевают организации, применяющие сбалансированную систему показателей / пер. в англ. Москва : ЗАО «ОлимпБизнес», 2004. 416 с.

4. Верба В. А., Гребешков О. М. Сучасні методичні підходи до оцінки ефективності маркетингової діяльності підприємства. URL: http://economica.org.ua/2009/ efmarkdijaln/

5. Герасимяк Н. В. Теоретико-методичні підходи до оцінки ефективності маркетингових заходів промислового підприємства. Економічний часопис-XXI. 2012. № 5-6. С. 40-43.

6. Колесник В. М. Методичні аспекти оцінки ефективності маркетингу в сільськогосподарських підприємствах зернопродуктового комплексу АПК. Економіка АПК. 2006. № 3. С.78-82.

7. Оцінка ефективності діяльності служби маркетингу. Критерії роботи служби маркетингу. URL: http://www.megos.org.ua/marketynh.13.13.html

8. Управління маркетинговими ресурсами. URL: http://marketopedia.ru/273marketing-resource-managementmrm.html

9. Усик С. П. Оцінка ефективності маркетингової діяльності вітчизняних підприємств. Економіка та держава. 2011. № 5. С. 33-38.

10. Щур О. М., Копець Г. Р. Удосконалення оцінки ефективності маркетингових витрат. Вісник нац. ун-ту «Львівська політехніка». Логістика. 2013. № 469. С. 333-337.

11. Микитюк П. П., Цетнар Л. О. Тенденції розвитку моделювання процесу маркетингових комунікацій підприємств-виробників спортивних товарів. Економічний простір. 2016. № 113. С. 206-219.

12. Микитюк П. П., Цетнар Л. О. Маркетингова оцінка ринку спортивних товарів у контексті професіоналізації сучасного спорту. Глобальні та національні проблеми економіки. 2016. Вип. 13. С. 334-338.

\section{References}

1. Antoniuk, A. A. (2007). Vybir pidhodiv do formuvannia pokaznykiv otsinky efektyvnosti marketynhovoi diialnosti na pidpryiemstvi [The choice of approaches to the formation of indicators for assessing the effectiveness of marketing activities 
in the enterprise]. Derzhava ta rehiony. Ser.: Ekonomika ta pidpryiemnytstvo - State and regions. Ser.: Economics and Entrepreneurship, 2, 11-14 [in Ukranian].

2. Kaplan, Robert S., Norton David P. (2004) Sbalansyrovannaia systema pokazatelei. Ot stratehyy k deistvyiu [Balanced scorecard. From strategy to action.]. Moscow: ZAO «Olimp-Biznes», 2004. 416 p. [in Russian].

3. Kaplan, R. S., Norton D. P. (2004) Orhanyzatsyia, oryentyrovannaia na stratehyiu. Kak $v$ novoi byznes-srede preuspevaiut orhanyzatsyy, prymeniaiushchye sbalansyrovannuiu systemu pokazatelei [Strategy-oriented organization. How organizations with a balanced scorecard thrive in the new business environment]. Moscow: ZAO «Olimp-Biznes», 416 p. [in Russian].

4. Verba, V. A, Hrebeshkov O. M. Suchasni metodychni pidkhody do otsinky efektyvnosti marketynhovoi diialnosti pidpryiemstva [Modern methodological approaches to assessing the effectiveness of marketing activities of the enterprise]. Retrieved from: http://economica.org.ua/2009/efmarkdijaln/ [in Ukranian].

5. Herasymiak, N. V. (2012) Teoretyko-metodychni pidkhody do otsinky efektyvnosti marketynhovykh zakhodiv promyslovoho pidpryiemstva [Theoretical and methodological approaches to assessing the effectiveness of marketing activities of an industrial enterprise]. Ekonomichnyi chasopys-XXI - Economic magazine-XXI, 5-6, 40-43 [in Ukranian].

6. Kolesnyk, V. M. (2006) Metodychni aspekty otsinky efektyvnosti marketynhu v silskohospodarskykh pidpryiemstvakh zernoproduktovoho kompleksu APK [Methodological aspects of assessing the effectiveness of marketing in agricultural enterprises of the grain complex of agro-industrial complex]. Ekonomika APK Economics of agro-industrial complex, 3, 78-82. [in Ukranian].

7. Otsinka efektyvnosti diialnosti sluzhby marketynhu. Kryterii roboty sluzhby marketynhu [Evaluation of the effectiveness of the marketing service. Criteria for the work of the marketing service]. Retrieved from: http://www.megos.org.ua/ marketynh.13.13.html [in Ukranian].

8. Upravlinnia marketynhovymy resursamy [Marketing resources management]. Retrieved from: http://marketopedia.ru/273-marketing-resource-managementmrm. html [in Ukranian].

9. Usyk, S. P. (2011) Otsinka efektyvnosti marketynhovoi diialnosti vitchyznianykh pidpryiemstv [Evaluation of the effectiveness of marketing activities of domestic enterprises]. Ekonomika ta derzhava - Economy and state, 5, 33-38 [in Ukranian].

10. Shchur, O. M., Kopets, H. R. (2013) Udoskonalennia otsinky efektyvnosti marketynhovykh vytrat [Improving the assessment of the effectiveness of marketing costs]. Visnyk nats. un-tu "Lvivska politekhnika». Lohistyka - Bulletin of National University "Lviv Polytechnic". Logistics, 469, 333-337. [in Ukranian].

11. Mykytyuk, P. P., Tsetner, L. O. (2016) Tendentsii rozvytku modeliuvannia protsesu marketynhovykh komunikatsii pidpryiemstv-vyrobnykiv sportyvnykh tovariv [Trends in the development of modeling the process of marketing communications of enterprises producing sporting goods]. Ekonomichnyi prostir - Economic space, 113, 206-219 [in Ukranian]. 
Ю. Микитюк, Є. Палковський

Оцінка маркетингової діяльності промислових підприємств з використанням ...

12. Mykytyuk, P. P., Tsetner, L. O. (2016) Marketynhova otsinka rynku sportyvnykh tovariv u konteksti profesionalizatsii suchasnoho sportu [Marketing assessment of the sporting goods market in the context of professionalization of modern sports]. Hlobalni ta natsionalni problemy ekonomiky - Global and national economic problems, 13, 334-338 [in Ukranian].

Статтю отримано 03 травня 2021 р.

Article received May 3, 2021 